\title{
Post-flânerie: How do mobile devices shape the experience of the city?
}

\author{
Gorsev Argin ${ }^{1,2, *}$, Burak Pak $^{2}$, and Handan Turkoglu ${ }^{1}$ \\ ${ }^{1}$ Istanbul Technical University, Department of Urban and Regional Planning, 34367 Istanbul, \\ Turkey \\ ${ }^{2}$ Altering Practices for Urban Inclusion Research Group, KU Leuven Sint-Lucas Brussels \\ and Ghent Campuses, Department of Architecture, 9000 Ghent, Belgium
}

\begin{abstract}
In the last decade, the advances in mobile technologies and location-based applications reshaped our mutual relationship with the urban environment. These technologies, as both a mean and barrier to the engagement between humans and their environment, have transformed the urban experience in profound ways. Urban experience is a relatively new concept introduced with the rise of modern cities in the nineteenth century. Its loss due to the rapid urbanization has been a subject of debate since then. Among the discussions that take place in this debate, the figure of 'flâneur' plays an extensive role. The flâneur is a figure who wanders through and appropriates the metropolitan city in pursuit of urban experience and reaps aesthetic meaning from the spectacle of the teeming crowds. Flânerie, or the act of wandering, and its implications for our understanding of urban life have been profound. Today, mobile technologies create a new kind of urban wanderer which is described as "post-flâneur". In this paper, by examining the altering concept of flânerie, we discuss the effects of mobile technologies on urban experience. Based on an informed study of a wide range of theories, we make reflections on the impact of mobile devices on the mutual relationship between humans and their environment, introduce key concepts for understanding the emergent phenomenon of post-flânerie and elaborate on its interconnections with the phenomena of cyber and hybrid-flânerie.
\end{abstract}

\footnotetext{
*Corresponding author: gorsevargin@gmail.com
} 


\section{Introduction}

The modern city of the nineteenth century introduced the figure of flâneur and the act of flânerie. Benjamin's [1] 'flâneur', a nineteenth-century character firstly portrayed by Baudelaire, walks in the city and observes rapidly transforming urban spaces of the modern city. This flâneur uses walking as a way of experiencing the city and uses this experience as a latent protest against the rapid alteration of the modern city. Although the flâneur was appropriating the rapidly evolving modern city by walking in it, Benjamin predicted that flâneur could not escape the fate of modern-self and the "loss of experience" was inevitable. In the 1950s, the Situationist movement brought back the concept of flâneur. This new the flâneur was walking through the city in search of an unplanned urban experience. Eventually, the urban experience, which was perceived as in favor of the modern city by Baudelaire, became something to fight for in the twentieth century. With the rise of consumer capitalism, a new kind of 'urbanian self' emerged, which has been described by Jameson [2] as the 'society of the image'. The Ghent Urban Studies Team [3] has identified this spectatorial consumer as 'neo-flâneur', which is the heir of Benjamin's middle-class flâneur.

Today, new technologies create a new kind of urban wanderer which can be named 'postflâneur'. Whether it is a smartphone, a tablet or a wearable technology, by using these mobile devices and location-based applications installed to these devices, people move through and experience the urban space in a whole new way. Furthermore, by using social media applications, people can record and share their memories along with their routes by attaching them to the specific geographic locations and re-appropriate the urban space by strolling, recording, and sharing it.

Within this context, the aim of this study is to understand how these mobile technologies affect the mutual relationship between humans and their environment and the act of postflânerie. The questions to be addressed are:

- How did the concept of flâneur evolve through time?

- What are the key concepts to understand and discuss the post-flâneur and differentiate it from other figures of flânerie?

- Is post-flânerie a loss or a rediscovery of the urban experience? And how is it related to the phenomena of cyber- and hybrid-flânerie?

To answer these questions, this paper examines various theories on the concept of flânerie that has been redefined and cited over time, and redefines the act of post-flânerie by providing critical reflections on these theories.

In this respect, the first part of the study will focus on the emergence and transformation of the concept of urban experience and the figure of flâneur (Section 2). Following this, the second part will examine urban experience in the era of mobile technologies and, by examining the evolution of flâneur, introduce the figure of the post-flâneur (Section 3). In the third part, the emergence of the post-flânerie will be discussed through four main alterations in the concept of flânerie; alterations in (re)construction of the 'city', rhythm, instruments of experience and instrumentalization of experience, and lastly, the concept of privacy (Section 4). The paper will conclude with final remarks on post-flânerie and future directions of the study (Section 5). 


\section{Urban experience and the flâneur}

The industrial revolution and the concomitant technological innovations of the nineteenth century had revolutionized the traditional city and constituted what we call the 'modern city'. Not only had the urban space dramatically changed, but also people who live in, their behaviors, everyday practices and the ways they imagine and experience these urban spaces [4]. At this point, flâneur takes the stage both as a product of and an attempt to appropriate modern city [5].

Benjamin, in his article on Baudelaire, revives the figure of flâneur and uses it in his study called "The Arcades Project" [1] (continued between 1927 and 1940) to investigate and examine the 'new' experience of an individual, or flâneur, with his terms, who walks in the city, observes rapidly changing urban space of the modern city and reaps aesthetic meaning from the spectacle of the teeming crowds [6]. According to him, a flâneur does not only walk but also tries to determine everything abolished and captured by capitalism while decoding the meaning of this new way of life [7]. This act of walking as a way of experiencing the city was a sort of a latent protest against the rapid alteration of the modern city and a mean to appropriate this changing urban phenomenon. Connerton [8] in his book "How Modernity Forgets", reminds us of De Certeau's [9] analogy, which suggests "act of walking is to the urban system what the act of speaking is to the language system", and describes walking as "a space of utterance; as speech is to language, so walking is to the appropriation of urban space". Although the flâneur was appropriating the altering modern city by walking in it, Benjamin predicted that the flâneur could not escape the fate of modern-self. According to him, 'loss of experience' was inevitable [10].

It is important to clarify what Benjamin means while using the word 'experience'. Although it is expressed with one word in English, the discussions on experience indicate two different understandings on experience. In German, these two different concepts are defined as erfahrung and erlebnis. Erfahrung means a more collective experience, such as a knowledge developed over time, while erlebnis indicates a more personal experience, that is to say, the act of experiencing. Contradictory to the thoughts of the theorists that state 'experience is no longer possible' and 'we are living in a society of experience' born from this duality, the former one means erfahrung while the latter one means erlebnis [11]. In this sense, the inevitable fate of loss declared by Benjamin should belong to the former one: the erfahrung.

It can be claimed that many criticisms on the modern city have struggled against this fate. In the second half of the 1950s, the Situationist movement defined a new discipline, which they called 'Psychogeography' to study "the effects of the geographical environment, consciously organized or not, on the emotions and behavior of individuals" [12]. The act of walking was the main tool of these scholars since in the act of walking, the body can trace a new map, one that escapes the rigid hierarchies of an imposed order [13]. Hereby, the concept of flâneur was back on stage again. This new flâneur was not walking the major roads and touristic districts determined by authorities but instead, by using methods such as 'dérive' went into every nook and cranny streets/districts of the city in a search for an unplanned urban experience.

Subsequently, at the beginning of the 1960 s, postmodern criticism of the modern city was on the rise $[14,15]$. This time, the main criticism was the loss of human-centered urban experience in modern cities. According to these critical voices, as a result of modern planning implementations, there had been an increasing hegemony of automobiles in urban space and 
walking-based urban experience had been interrupted. Two decades later, these arguments bring along New Urbanism, which advocates "livable" spaces at the human scale [16]. Thus, determining spatial organizations which provide walking and perceiving the city from a human perspective became the main interest of the postmodern urban scholars $[17,18]$.

In the 1980s, with the rise of consumer capitalism, the urban space itself became the subject of commodification [19]. One of the visible aspects of this commodification is the increasing instrumentalization of public spaces for the advertisements, which, in turn, leads to the loss of self-control over visual perception during a daily walk. McCormick [20] defines his walking experience in Melbourne streets as a comprehension of the loss of public space. He adds that we still have streets, shops, parks, however, there is no urban space that we do not hear or see messages that force us to buy something [20]. Jameson [2] defines the new society which has been in a rise in last decades as "a new 'society of the image' in which consumerism and market frenzy are not the issue so much as consumption by the eyes". Based upon this definition, The Ghent Urban Studies Team [3] introduced the phenomenon of 'neo-flâneur' who is "today's spectatorial consumer" that "should be seen as a direct heir to the popular middle-class flâneur described by Benjamin" [3]. The main goal of the neoflâneur is not necessarily drawing alternative aesthetic meanings and experiences but purely market-driven consumption.

\section{Urban experience in the era of mobile devices and the post- flâneur}

Urban experience is a relatively new concept which has been a subject of debate following the rise of modern cities. Furthermore, loss of urban experience due to the rapid alteration of the urban spaces seemed to be the key concern of further critics of the modern city within these discussions. Today, urban experience has reached a new level due to the advances in mobile technologies that have rapidly penetrated into and shaped our daily lives. As Castells [21] explains, today, we are walking in a built environment "that is increasingly incorporating electronic communication devices everywhere" and we live in "a new urban form in which we constantly interact, deliberately or automatically, with online information systems, increasingly in the wireless mode".

Today, the urban experience is generated by digital information mediated by mobile devices in ways that were not possible just a decade ago [22]. One of the most current examples of these mobile devices are smartphones, which have been adopted more rapidly than any other technologies in the history [23] and has an extraordinary rising rate all over the world [24]. 
These mobile technologies offer new perspectives to individuals but also emerge as a mean and barrier to novel forms of urban life and its experience. Today, it is the question that whether people walking on the streets with their heads down with their mobile phones are still a part of the street life or not [25]. Urban life consists of everyday mobile encounters in the streets and visual, or face to face interaction, is a key feature of these encounters [16]. As a result of mobile technologies, people are no longer automatically part of these encounters, half of them "there in body but not in any other way" [25, 26]. This also affected the figure of flâneur profoundly (Figure 1).

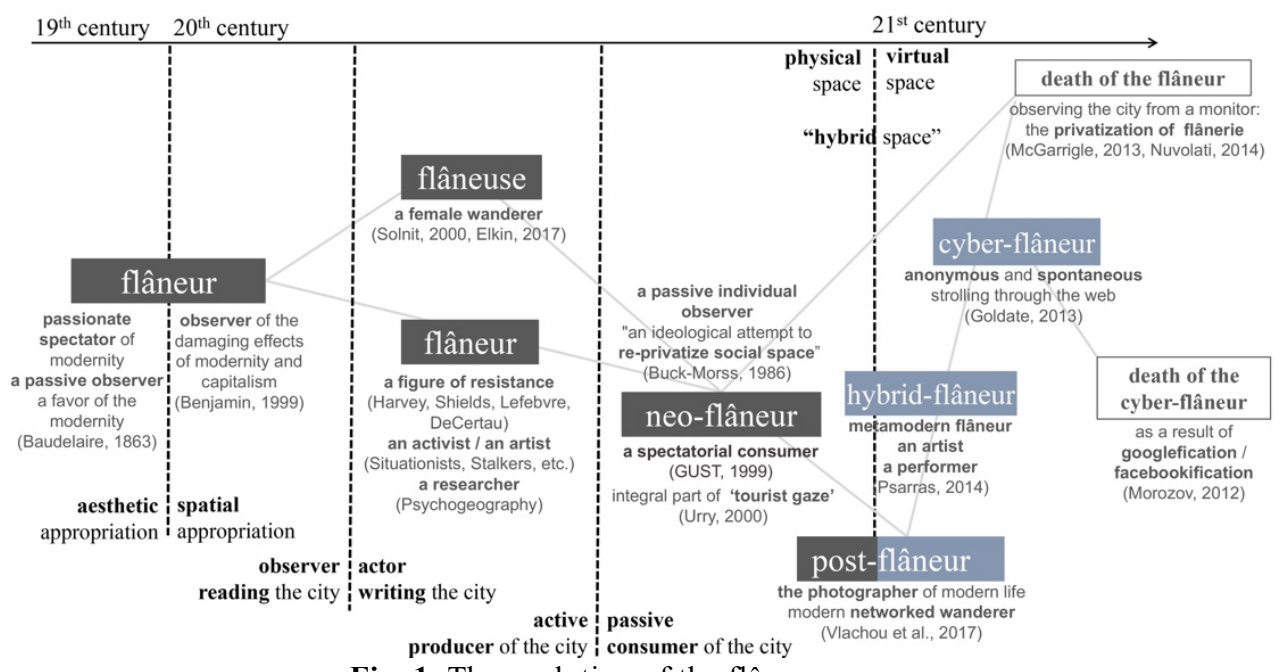

Fig. 1. The evolution of the flâneur.

\subsection{Death and resurrection of the flâneur}

Baudelaire's and Benjamin's flâneur are both the observers of the modernity. The former walks through the city for an aesthetic appropriation while the latter slides towards the spatial appropriation of the altering urban space. According to Benjamin, flâneur is the person who observes the damaging effects of capitalism and his extinction is inevitable as the loss of experience. When flâneur takes the stage again in the late 1950s and 1960s, he - and this time also she - is not only an observer who reads the city but instead is an actor who writes the city. He/she appears as a figure of resistance, an activist, an artist or a researcher. With the rising commercialism in 1980s, the figure of flâneur comes to the threshold of death but doesn't die. However, Benjamin is right about the fate of the urban experience. Flâneur who turns into 'neo-flâneur' [3], a "puppet in the hands of capitalism" [5], a "passive individual observer" [27] or a tourist [28] who perceives the urban environment from pre-scripted perspectives and becomes the consumer of the city and the urban experience that appears only as an erlebnis.

In the twenty-first century, with the advances in technologies, the virtual space has become a new wandering ground for the flâneur. In-between the death announcements of the "old" flâneur [29, 30], a new wanderer who strolls in the endless possibilities of the web was born and called as 'cyber-flâneur' [31]. Cyber-flâneur has some similarities with the classical figure of flâneur. Both of them spontaneously wander their environment which is a virtual space for the former and a physical space for the latter. Cyber-flâneur also has a similar fate 
to his/her ancestors. With the rise of guiding search engines and social networking websites, the guides became the directors of the surfing experience and anonymous and spontaneous nature of strolling came to an end [32].

\subsection{Emergence of hybrid space and the post-flâneur}

With the advances in mobile technologies, a new 'hybrid' space was born in between the physical and virtual spaces. This hybrid space brings the flâneur back to the stage one more time. It is redefined with respect to the different challenges that came with mobile technologies and called as hybrid-flâneur [33] or post-flâneur [34]. Psarras [33] defines the hybrid-flâneur as the "metamodern flâneur" who acts as an artist and a performer. Postflâneur, on the other hand, can be anybody who walks the city with his/her smartphone, takes photographs and shares them in the social media, who can be called the "photographer of modern life" or the "modern networked wanderer" [34].

This paper, on the other hand, uses the term of post-flâneur in a wider context, to define a wanderer with a mobile device who shuttles between the virtual and physical space in pursuit of an urban experience. Whether he/she takes photographs or navigates through his/her mobile device, the aim of the walk should be the experience itself.

\section{Key concepts for understanding the post-flâneur}

In this part of the paper, post-flânerie will be examined through the key concepts reflect behavioral and perceptual similarities and differences between various states of flânerie which are alterations in the (re)construction of the 'city', rhythm, instruments of experience and instrumentalization of experience, and lastly, the concept of privacy.

\subsection{Walking and (re)construction of the 'city'}

Flânerie is a way of wandering through the parts of the city and seizing its details. Moreover, it also means to provide a perception and narrative about the 'city' as a whole. As mentioned before, De Certeau [9] suggests that the act of walking means for the city in the same way as the act of speaking means for the language. Perceiving the city by walking was much easier in the traditional city, which was a unity. However, that unity has become fragmented in the course of time due to the rapid urbanization. The citizens have been alienated from the traditional city and become unable to mentally map their own positions and the urban as a unity [14].

In the years when Debord suggested the act of dérive as a version of a flânerie, Paris was in a somewhat rapid urbanization process. Perceiving the city as a whole - which can exist only in a virtual state - was becoming more and more difficult for the citizens [35]. The aim of the dérive was to make the city a unity again, a unity which is in motion and transformation [35]. With this purpose, Situationists were simultaneously walking in the streets of physically separated parts of the city and sharing their experiences concurrently by using all kinds of mobile communication tools such as walkie-talkies [35]. This pursuit of unity had been continued until the 1960s when it became impractical due to the undeniable mass urbanism.

Today, we have collective digital maps reachable from mobile and online devices developed by large communities. A post-flâneur can walk through the city by both using and contributing these maps. It should be underlined that dérive maps show significant 
distinctness from the current collective digital maps in many ways (i.e. aims, ideologies, representations, etc.). Nonetheless, the unity of the city that can only exist in the virtual state is becoming more visible both in the virtual and also in the hybrid space as a result of the advances in mobile technologies and especially location-based mapping tools. Today, people who do not know each other can walk on the streets and share their comments and experiences simultaneously. The form of these narratives can differ depending on the sharing tools. In this way, a collective map of the city defines a 'new' whole which is constantly in motion and transformation. The people who make this map are not members of a small group like the Situationists, however, they have to be a member of a wider group (perhaps this one is much easier to enter) to exist in these platforms.

It should also be added that flânerie, in the classical sense, does not need any guidance of a map. Psychogeographers, in some of their flâneries, go one step further and use maps contradictory to its raison d'être by using maps of different cities [13]. For a post-flâneur, on the other hand, maps become a default instrument comes along with mobile devices. Today, as a result of the advances in mobile devices and location-based applications, post-flâneurs wander through the representation of the city as a network of coordinated places, data, and etc. The "blue dot", or the avatar of the post-flâneur, wanders through this virtual representation of the city, at the same time, the post-flâneur strolls in the actual physical space. In one sense, this is a reflection of an egocentric walking experience into an exocentric representation of the experience. For a post-flâneur who uses the navigation of the mobile device or takes and shares photographs by adding location information, the representation of the city in his/her mind should be different from the previous flâneurs.

\subsection{Altering rhythm: walking the turtle to walking with a smartphone}

According to De Certeau [9], if we think about "the memorable here and there", which is often incited by walking in the city, memory is kind of a spatial practice [23]. Since spatial memory requires a certain measure of stability, walking - by establishing oriented things as identical things and hence constituting a "steady system of places" - contributes to the construction of spatial memory and "a particular pace of assimilation" makes a place and what is experienced there, memorable [8].

The city has always been in a rush compared to the rural areas [36]. However, by the turn of the twenty-first century, the tempo of the city has been increased from many perspectives. This phenomenon has been explained by certain theories such as "hyper-acceleration", "turbo-capitalism" and the "digital speed revolution" [37]. Respectively, the effect of this capitalism on urban space has been conceived as the altering tempo of everyday rhythm and therefore resulted in the change of walking speed in the urban environment. Plus, with the introduction of new and faster mobility forms, a new form of flow has captured the city. Castells [21] attributes this new urban phenomenon to the era of "space of flows rather than a space of places". This is generally related not only to the acceleration phenomenon of social life but also to urban life.

Benjamin refers to the walking men with their turtles while narrating the flâneur who walks through the nineteenth-century streets and arcades. In these walks, the turtle decelerates the pace of the flânerie, thus, the flâneur who keeps this pace experiences the environment from a different perspective. In his novel "Slowness", Kundera [38] expresses his longing for the flâneurs of the past and asks the question of "Why has the pleasure of slowness disappeared?". In fact, by giving the example of flâneurs with turtles, Benjamin himself emphasizes the tempo of a flânerie [27] and addresses this kind of pleasure of 
slowness. Kundera [38] also defines a correlation between slowness and memory and between speed and forgetting. This brings to mind Benjamin's use of the term 'experience' in the meaning of erfahrung which also can be associated with the memory.

If we imagine a post-flâneur walking with its smartphone in today's 'hyper-accelerated' world, we may conjure a mental picture of a person who frequently slows down and stops. This may also mean that the post-flâneur, that his/her ancestors have been flowing in the crowds, may interrupt or change the flow from time to time. An extreme example of this is called as the smartphone zombie, "who walks slowly and without attention to their surroundings because they are focused upon their smartphone" [39]. In this sense, this figure is quite far away from the post-flâneur, by moving physically in the crowd while mentally strolling in another world far from the crowd.

Whether used for taking pictures or finding directions, mobile devices often determine or at least influence the pace of the walker. A post-flâneur who wants to take a picture firstly slows down in seeking of a desired frame and mostly stop to press the shutter or a navigator post-flâneur's actions on the map reflect his/her walking actions [40]. However, the aim behind the slowness in a post-flânerie can be questionable. Is it a pursuit for physical and mental engagement with the environment or a way of using the mobile device as a mean of virtual engagement? It can also be claimed that the slowness of turtle stimulates the instant experience while slowness provided by smartphone is an arrangement for the next experience.

\subsection{Instruments for experience and instrumentalization of experience}

Flâneur, in its classical meaning, uses walking as an instrument for the urban experience. Besides, he/she uses a variety of instruments to accompany this walk. Benjamin's flâneur walks with a turtle while some of the situationists use walkie-talkies in their dérive experiments. Today, the widely-used instrument for the post-flâneur is smartphones and applications that help to capture, record, share, navigate, and etc.

All of these instruments change people's perceptions of their environments. The increasing use of photography in everyday practice due to the advances in smartphones and the rise of visual narratives is a case in point. Related to advances in mobile technologies and social media platforms, human beings are no longer interested only with the environment as itself, but also "in the representation, recording, management and monitoring of these environments", to put it another way, this is not only about the environment, but rather it's versions that "invented, idealized, perceived and experienced through countless filters" [41]. These also reflect the post-flâneur's relationship with the city. According to Young [42], it has been weakened and loosened as media representations of the city have evolved.

The post-flâneur, who is defined as the "photographer of the modern life" [34], walks in search of creating this kind of representations of the city. This figure can also be read as a version of Baudelaire's "painter of the modern life" who walks the city in a search for an aesthetic appropriation. However, this flâneur does this appropriation by photographing and uploading images to social media in which his/her attention is increasingly concentrated on their mobile phone screen and reactions to these images [34]. To put it another way, in some cases taking and sharing the photo become the main aim of the post-flânerie in which the experience itself became an instrument. Today, a photographer post-flâneur's flânerie can be under the pressure of finding the "perfect" photo whose criteria have been built by the influencers. 
We can witness the instrumentalization of experience also in the other forms of flânerie. As mentioned before, Benjamin's flâneur, from time to time, walks through the city in an attempt to protest latently the transformation of the city due to the rapid urbanization. Furthermore, in the 1950s, the flâneur starts to walk in an ad hoc manner. For instance, the main aim of a flânerie can be creating situations for a Situationists, while it can be doing ethnographic research for a Psychogeographies. However, the significance of the "real" experience is still prominent in these examples.

As already mentioned earlier, the crisis of experience has been on the table every time the flâneur has been brought to the stage. Today, if we live in a world of experiences and hear and use the word 'experience' consistently, this may tell us that the 'experience' (erfahrung) which is in crisis has already come to an end and the act of 'experiencing' (erlebnis) has taken its place. The instrumentalization of experience today means precisely the instrumentalization and consumerism of this somewhat erlebnis.

\subsection{Figure of privacy and the privacy of the figure}

The alteration in the relationship between the flâneur and the concept of privacy can be discussed from two perspectives. The first one is transformation of the figure of post-flâneur into a figure of privacy [31] every time he/she gives his/her attention to the virtual space through the mobile device. The classical figure of flâneur, the man of the crowd [6], strolls within the flows of the modern city while engaging with the urban environment physically and mentally. On the other hand, post-flâneur who shuffles between the physical and the virtual space by using his/her mobile device, from time to time, focuses on the virtual and moves away mentally from the surrounding crowd. This isolation creates some limitations on the real-world engagement. Bull [43], in his article that announces "the end of flânerie", indicates the emergence of somewhat "mediated urban isolation" for the people who listen music with their mobile devices while walking. In light of these, it can be claimed that, today, as a result of mobile technologies people are no longer automatically part of the city and the walking experience. Golberger [31] defines the effect of this situation on post-flânerie by giving a cell phone example:

“...even when the phone does not ring at all, and is being used quietly and discreetly, it renders a public place less public. It turns the boulevardier into a sequestered individual, the flâneur into a figure of privacy" [31]

The second transformation in the concept of privacy can be seen in the privacy of the flâneur. From the very beginning, the major things that make possible the concept of flânerie has been the expanding understanding of the city and the growing crowd in it. That is to say, the classical figure of flâneur was trying to blend into this crowd in order to see without being seen [44], to stroll freely by the help of anonymity. The birth of cyber-flâneur was also a product of a somewhat anonymity derived by the early internet experiences, and its death was announced with the end of this anonymity.

Today, almost every act in the virtual space leaves footprints behind. This also questions the anonymity of the post-flâneur since every information about the physical space or its representation produced or consumed by post-flâneur in the virtual space can be traceable. One step further, countless applications track its users in the name of providing personalized experiences. In the case of post-flânerie, this also jeopardizes the spontaneity and anonymity of the strolling, firstly due to the incongruity of pre-scripted experience with the nature of 
flânerie, and secondly due to the genericization of their online 'personality' since they are mainly developed for target groups instead of individuals.

\section{Conclusions and future directions}

The flâneur of the twenty-first-century hybrid space; post-flâneur, is a wanderer who is walking through the city accompanied by his/her mobile device(s), wandering between the physical and virtual space in pursuit of an urban experience. In a way, these devices can be a helpful instrument for the post-flâneur since they can provide an enhanced urban experience by guiding individuals through an immersive and interactive environment with valuable information [45]. From this perspective, it can be claimed that post-flânerie still provides an experience and this means the experience has not been lost but transformed. This transformation occurred in the meaning of experience and it is not only the result of advances in mobile technologies but mostly related to the "spirit of the age" we are in. With this respect, today, when we are discussing the effects of mobile technologies on the experience of post-flâneur; firstly, we should underline the paradigm shift in the meaning of experience, from erfahrung to erlebnis, collective to personal experience.

Benjamin's flâneur was walking in an age of erfahrung. In today's world of high-speed society, erfahrung is in a crisis. Erlebnis insists that more personal experience substitutes this. Today, we are living in an era in which the state of 'experiencing' surround us on every side. Correspondingly, the twenty-first-century relationship between human and the city has mainly described by referring to a somewhat personal experience (erlebnis). At this point, it is important to remember that, Benjamin's friend Adorno [46] gives attention to the commercialism of these kinds of experiences (erlebnis) and puts a question mark on their 'personality'.

The rise of personal experience (erlebnis) and its commercialism have been in the front burner for a long time and their effects on flânerie can also be seen in the 'spectatorial consumer' of the late twentieth century: the neo-flâneur [3]. However, with the emergence of hybrid space mediated through mobile technologies, there has been another alteration within the erlebnis itself.

Hybrid space emerged as a result of the coexistence of and interactions between digital information, and communication flows and the physical space. This interaction was not on an ex parte basis. While the latter is affecting the physical environment and its perception, the former and its experience started to settle in the virtual space within the form of its representations and narrations. With the advances in mobile technologies, social networks, and location-based applications, these representations of the physical space and its experience also became a significant part of everyday life. Today we are living in a world of representations [47]. Especially, with the introduction of visual-based mass communication tools (i.e. Instagram), the experience of representation of the "real" has been substituted the "real" experience. This also accompanied by a paradigm shift from private experience to shared experience. In some cases, experience of sharing the experience can substitute the "real" experience. In this context, we can also claim that a new kind of erfahrung has reemerged in the virtual as an online social experience substituting the real.

In light of these, building on the reality-virtuality continuum of Milgram et al. [48], we suggest redefining the term of post-flâneur as a continuum between the flâneur and cyber-flâneur. Today, when a post-flâneur engages with physical space without any mediation of mobile technology and experience the 'reality', he/she approaches a flânerie 
(Figure 2). This flânerie, naturally, has distinctions from the older ones due to the changes in the concept of experience through time. The anonymity of this figure can also be questioned in an era that face-recognition systems have been spreading towards the public space. However, it can also have some similarities in terms of the cognitive construction of the space and the rhythm of the pace. On the other hand, when a post-flâneur's attention is increasingly concentrated on the virtual, he/she approaches to the cyber-flâneur. In this situation, the experience is again open to discussion in terms of the degree of the relation of the experience with the reality.

\begin{tabular}{ccr} 
flâneur & post-flâneur & cyber-flâneur \\
\hline$<$ Real & Hybrid & Virtual $>$
\end{tabular}

Fig. 2. Post-flâneur as a continuum between the flâneur and cyber-flâneur.

The post-flâneur can also be located in the middle of this continuum in which he/she experiences the "reality" through its representations in the virtuality. Here, it will be convenient to address Baudrillard's [47] four degrees of representation which are the representations that reflect directly the reality, masks and filters the reality, masks the absence of the reality, and lastly the simulation which has no relation with the reality. Accordingly, when the representation used or produced by the post-flâneur approaches to simulation, the act of post-flânerie moves away from the reality and the experience of this reality.

It is clear that, in the near future, humans are going to get more and more connected to the virtual world, and the hybrid space mediated through mobile technologies will be more dominant. This means that the perception of the urban space and its experience will continue to transform. At this point, the emergent phenomenon of post-flânerie gives us a chance to observe and discuss the effects of these mobile technologies on urban experience and offers a contextual framework towards the future of urban experience. In this context, the further step of this study will be to go on the field, observe post-flâneurs in the urban crowd and examine the key concepts introduced the degree of dominance of the virtual representations mediated by mobile technologies on the post-flânerie. This observation can be conducted at least at two levels: from a behavioral perspective of the "outsider" and through the eyes of the post-flâneur. Both of these can provide complementary knowledge which can help us understand the emergent phenomenon of post-flânerie deeper, lead to novel ways of rethinking and designing our future cities.

This paper is produced as a part of a Ph.D. dissertation on Post-flânerie by the first author supervised by the second and the third authors. 


\section{References}

1. W. Benjamin, The Arcades Project (The Belknap Press of Harvard University Press, Cambridge, 1999)

2. F. Jameson, London Review of Books, 18, 7 (1996)

3. GUST, The Urban Condition: Space, Community, and Self in the Contemporary Metropolis (010 Publishers, Rotterdam, 1999)

4. R. Solnit, Wanderlust: A History of Walking (Viking, New York, 2000)

5. C. Jenks and T. Neves, Cultural Values, 4, 1(2000)

6. K. Tester, "Introduction," The Flâneur (Routledge, New York, 1994)

7. A. Oktay, Metropol ve İmgelem (Türkiye İş Bankası Kültür Yayınları, Istanbul, 2002)

8. P. Connerton, How Modernity Forgets, (Cambridge University Press, Cambridge, 2009)

9. M. De Certeau, The Practice of Everyday Life (University of California Press., Berkeley, CA, 1984)

10. M. Hansen, Public Culture, 5, 2 (1993)

11. M. Jay, Songs of experience: Modern American and European variations on a universal theme (University of California Press., Berkeley and Los Angeles, 2005)

12. G. Debord, Les Lèvres Nues, 6 (1955)

13. T. Richardson, Walking inside out: Contemporary British psychogeography (Rowman \& Littlefield International, Ltd., Lanham, Maryland, 2015)

14. K. Lynch, The image of the city (Technology Press., Cambridge Mass, 1960)

15. J. Jacobs, The death and life of great American cities (Random House, New York, 1961)

16. J. Middleton, Urban Stud., 55, 2 (2018)

17. W. H. Whyte, The social life of small urban spaces (Conservation Foundation, Washington, D.C., 1980)

18. J. Gehl, Life between buildings: Using public space (Van Nostrand Reinhold, New York, 1987)

19. D. Harvey, The condition of postmodernity: an enquiry into the origins of cultural change (BasilBlackwell, London, 1989)

20. M. McCormick, Dialogue, 4 (1996)

21. M. Castells, "Space of Flows, Space of Places: Materials for a Theory of Urbanism in the Information Age," The Cybercities Reader (Routledge, London, New York, 2004)

22. M. J. Kelley, GeoJournal, 79, 1 (2014)

23. J. Kalin and J. Frith, Rhetor. Soc. Q., 46, 3 (2016)

24. P. R. Center, "Smartphone Ownership Is Growing Rapidly Around the World, but Not Always Equally" (2019)

25. P. Goldberger, "Our Cell Phones, Our Disconnected Selves" (2013) [online, accessed 9.2.2019] Available at: https://www.metropolismag.com/ideas/paulgoldberger-cell-phones-disconnected-selves/

26. M. De Waal, The City as Interface: How new media are changing the city (nai010 Publishers, Rotterdam, 2014

27. S. Buck-Morss, New Ger. Crit., 39, 99-140 (1986)

28. J. Urry, Sociology Beyond Societies: Mobilities for the twenty-first century (Routledge, New York, 2000)

29. C. McGarrigle, 19th International Symposium of Electronic Art (2013) 
30. G. Nuvolati, "The flâneur: A way of walking, exploring and interpreting the city," Walking in the European City: Quotidian Mobility and Urban Ethnography (Routledge, 2014)

31. P. Goldberger, "Paul Goldberger on Our Cell Phones, Our Disconnected Selves" (2013) [Online, accessed 9.2.2019] Available at: https://www.metropolismag.com/ideas/paul-goldberger-cell-phones-disconnected$\underline{\text { selves }}$

32. E. Morozov, "The Death of the Cyberflâneur" (2012) [online, accessed 9.2.2019]

Available at: https://www.nytimes.com/2012/02/05/opinion/sunday/the-death-of-thecyberflaneur.html

33. B. Psarras, "Initial Reflections on a 'Metamodern' Flâneur" (2015) [online, accessed 9.2.2019] Available at: https://hybridflaneur.wordpress.com/2015/06/09/on-a-metamodern-flaneur-pt-i/

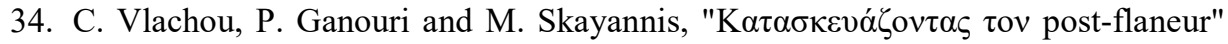
(2017) [online, accessed 9.2.2019]

Available at: http://gavagaiphilosophy.weebly.com/uploads/8/2/0/0/82000672/1.pdf

35. H. Lefebvre, Henri Lefebvre on the Situationist International [Interview] (1983)

36. D. Harvey, Paris, Capital of Modernity (Routledge, New York, 2003)

37. H. Rosa, Constellations, 10, 1 (2003)

38. M. Kundera, Slowness (HarperCollins Publishers, New York, 1995)

39. J. Mwakalonge, S. Siuhi and J. White, J. Traffic Transp. Eng. Eng. Ed. 2, 5 (2015)

40. E. Laurier, B. Brown and M. McGregor, Mobilities, 11, 1 (2016)

41. R. Coyne, Interactions, 21, 5 (2014)

42. S. Young, Scan: Journal of Media Arts Culture, 2, 1 (2005)

43. M. Bull, "The End of Flânerie: iPods, Aesthetics, and Urban Experience," Throughout (The MIT Press, Cambridge, Massachusetts, London, 2012)

44. Z. Bauman, "Desert spectacular," The Flâneur (Routledge, New York, 1994)

45. O. Guntarik, J. E. Garcia, S. R. Howard and A. G. Dyer, Leonardo, 51, 2 (2018)

46. T. W. Adorno, Aesthetic theory (Routledge and Kegan Paul, London, 1984)

47. J. Baudrillard, Simulacra and simulation (University of Michigan press., Ann Arbor, 1994)

48. P. Milgram, H. Takemura, A. Utsumi and F. Kishino, Telemanipulator and Telepresence Technologies (1994) 